\title{
Influence of Integrated Nutrient Management on Paddy (Oryza sativa 1.) under Hill Zone of Karnataka
}

\author{
Shreeshail $^{1}$, M. Hanumanthappa ${ }^{1 *}$ and M. Ganapathi ${ }^{2}$ \\ ${ }^{1}$ Department of Agronomy, ${ }^{2}$ Department of Crop Physiology, College of Horticulture, \\ Mudigere, Karanataka, India \\ *Corresponding author
}

\section{Keywords}

Paddy, Integrated nutrient management,

Eupatorium,

Glyricidia, PGPR

Article Info

Accepted:

18 January 2020

Available Online:

10 February 2020

\section{A B S T R A C T}

A field experiment was conducted at Zonal Agricultural and Horticultural Research Station, Mudigere, Chikkamagaluru district, Karnataka to investigate the integrated nutrient management in paddy under hilly zone of Karnataka during kharif season of 2018. The experiment was laid out in Randomized Complete Block Design consisting of ten treatments and three replication. The result revealed that application of $100 \%$ RDF + Glyricidia (50\%) + Eupatorium (50\%) + PGPR recorded significantly higher plant height $(99.06 \mathrm{~cm})$, number of leaves(71.26), number of tillers per hill (23.86), leaf area(1098 cm2 hill-1), leaf area index(5.49) and total dry matter (59.69 $\mathrm{g}$ hill-1) over other treatments. Growth parameters such as AGR, RGR and CGR showed significant differences among all the treatments.at 60-90DAT and 90DAT- harvest. The yield and yield attributing parameters like number of productive tillers per hill $(18.41)$, panicle length $(22.29 \mathrm{~cm})$, panicle weight( $4.13 \mathrm{~g}$ hill-1), total number of grains(128 panicle-1), 1000 grain weight(25.36g), grain yield(5843kg ha-1) and straw yield(7477 $\mathrm{kg}$ ha-1) was recorded significantly higher with the application of 100 per cent recommended dose of fertilizers + Glyricidia $(50 \%)$ + eupatorium $(50 \%)$ + PGPR(T9), followed by 100 per cent recommended dose of fertilizers + FYM + PGPR(T5) and the lowest was recorded in 100 per cent recommended dose of fertilizers.

\section{Introduction}

Rice (Oryza sativa L.) is the leading cereal food crop of the world contributes as the principle food for about 62 per cent of the world's population. India is the world's second largest rice producer and consumer after China. Rice cultivation faces challenges across the world and India is no exception, with a reduction in area in most of the regions due to fluctuation in production and productivity, stagnating yields and everincreasing input cost besides labour scarcity. India needs to produce $135-145 \mathrm{~m}$ t of rice by 2020 to feed the additional 350 million people (Prakash et al., 2008).

Due to continuous and imbalance use of chemical fertilizers adversely affects soil health and nutrient reserve, resulting in environmental pollution and concern for sustainable agriculture and ultimately the 
yield. The basic concept of integrated nutrient management is to maintain soil fertility, sustainable agricultural productivity and improving farmer's profitability through judicious and efficient use of fertilizers, organic manures and biofertilizers.

Green manures, farm yard manure (FYM) and crop residues are important sources of organic matter. Adequate availability of FYM, is one of the best organic source, is seriously constrained by the use of dung as fuel in India. As an alternative, the green manure crops like dhaincha, sunhemp, cowpea, eupatorium and glyricidia etc. have the advantage of vigorous growth habit, $\mathrm{N}$-fixing capacity and the ability to withstand a wide range of soil conditions. Green manuring is a practice of turning green biomass in the soil to improve the soil physico-chemical and biological properties suitable for plant growth and are excellent alternative to chemical fertilizers for sustainable agriculture.

Change in cropping sequence with respect to availability of resources the integrated approach of nutrient supply through inorganic and organic, has become very much promising in building soil health and quality of produce. Currently, growth of rice plants uses a lot of chemical fertilizer and chemical pesticide.

The increase of production of paddy must be achieved through improvement in agricultural productivity. Microbes are the beneficial key factors in maintaining soil quality by decreasing the dose of chemical fertilizers and increasing the crop production.

\section{Materials and Methods}

A field experiment was conducted during kharif season of 2018 at Zonal Agricultural and Horticultural Research Station, Mudigere, Chikkamagaluru district, Karnataka, to study the integrated nutrient management in paddy. The experimental site is located at $13^{\circ} 7^{\prime}$ North latitude and $74^{\circ} 37^{\prime}$ East longitude with an altitude of $980 \mathrm{~m}$ above mean sea level. The soil of the experimental site was sandy loam in texture and $\mathrm{pH}$ was acidic (6.15), with normal salt load (EC $\left.0.053 \mathrm{~d} \mathrm{Sm}^{-1}\right)$. The organic carbon content was low $\left(4.7 \mathrm{~g} \mathrm{~kg}^{-1}\right)$. The soil was medium in available nitrogen $\left(325.00 \mathrm{~kg} \mathrm{ha}^{-1}\right)$, high in available phosphorus (62.01 kg ha ${ }^{-1}$ ) and medium in available potassium (102.27 kg ha ${ }^{-1}$ ). KHP-13 a popular variety was transplanted in July with a spacing of $20 \mathrm{~cm} \times 10 \mathrm{~cm}$.

The experiment was laid out in Randomized Complete Block Design consisting of ten treatments and replicated thrice. The treatment combination includes $\mathrm{T}_{1}-100 \%$ $\mathrm{RDF}, \mathrm{T}_{2-}-100 \% \mathrm{RDF}+\mathrm{FYM}, \mathrm{T}_{3}-100 \%$ $\mathrm{RDF}+$ Glyricidia equivalent to $\mathrm{FYM}, \mathrm{T}_{4}-100$ $\% \mathrm{RDF}+$ Eupatorium equivalent to $\mathrm{FYM}, \mathrm{T}_{5^{-}}$ $100 \% \mathrm{RDF}+\mathrm{FYM}+\mathrm{PGPR}, \mathrm{T}_{6}-100 \% \mathrm{RDF}$ + Glyricidia+ PGPR, $\mathrm{T}_{7}-100 \% \mathrm{RDF}+$ Eupatorium+ PGPR, $\mathrm{T}_{8^{-}} 100 \% \mathrm{RDF}+$ PGPR, $\mathrm{T}_{9}-100 \%$ RDF + Glyricidia (50\%) + Eupatorium $(50 \%)+$ PGPR and $\mathrm{T}_{10^{-}} 100 \%$ $\mathrm{RDF}+$ Glyricidia $(50 \%)+$ Eupatorium $(50 \%)$.

The organic manures were incorporated in soil 25 days before transplanting of paddy. Yield (biological and economical) was recorded from individual plots at harvest and expressed in $\mathrm{kg} \mathrm{ha}^{-1}$ Standard statistical methods were used for comparing the treatment means.

\section{Results and Discussion}

\section{Mopho-Physiological Parameters}

Influence of integrated nutrient management on mopho-physiological parameters such as plant height, number of leaves, number of tillers, leaf area, leaf area index and total dry matter at 90 DAT is presented in Table-1. 
All the mopho-physiological parameters showed significant differences due to integrated nutrient management. Significantly maximum plant height $(96.74 \mathrm{~cm})$, number of leaves (71.26), number of tillers (23.86), leaf area $\left(1098 \mathrm{~cm}^{2}\right.$ hill $\left.^{-1}\right)$, leaf area index $(5.49)$ and total dry matter $(59.69 \mathrm{~g})$ was observed in treatment $\mathrm{T}_{9}-100$ per cent $\mathrm{RDF}+$ glyricidia $(50 \%)+$ eupatorium $(50 \%)+$ PGPR followed by $\mathrm{T}_{5}-100$ per cent RDF + FYM + PGPR 100 per cent RDF + glyricidia + PGPR $(94.34 \mathrm{~cm})$ and the lowest was recorded in $\mathrm{T}_{1^{-}}$ $100 \%$ RDF.

Combined application of inorganic and organic nutrients recorded higher mophophysiological parameters might be due to direct and more availability and translocation of nutrients during developmental phase of crop growth, which accelerated the metabolic and physiological activity of the plant and put up more growth by assimilating more amounts of nutrients and facilitated more photosynthesis. Similar findings were also reported by Sunil Kumar et al., (2017), Ogundare et al., (2015) and Macedo (2008).

Significantly maximum leaf area, leaf area index and total dry matter production was recorded with treatment $\mathrm{T}_{9}-100$ per cent $\mathrm{RDF}+$ glyricidia $(50 \%)+$ eupatorium $(50 \%)$ + PGPR and it was followed by $\mathrm{T}_{5}-100$ per cent RDF + FYM + PGPR 100 per cent RDF + glyricidia + PGPR.

This might be due to adequate supply of nitrogen through INM had produced larger leaves which in turn, resulted in more photosynthetic surface area. The significant response with leaf area might be due to addition of green manures that tend to increase the respiration rate, metabolism and growth of plants (Gangwar and Dubey, 2013), (Singh and Agarwal, 2001) and (Jamilah and Juniarti, 2017).
Leaf area fairly gives a good idea of the photosynthetic capacity of the plant. In the present study leaf area and leaf area index increases drastically up to grand growth period and decreases there after towards maturity.

\section{Growth Parameters}

Influence of integrated nutrient management on growth parameters is furnished in Table-. 2

The data on AGR, RGR and CGR differed significantly between 60-90 days after transplanting. Significantly higher AGR, RGR and CGR was recorded in treatment $\mathrm{T}_{5^{-}}$ $100 \% \mathrm{RDF}+\mathrm{FYM}+\mathrm{PGPR}, \mathrm{T}_{8}-100 \% \mathrm{RDF}$ + PGPR and $\mathrm{T}_{6} 100 \% \mathrm{RDF}+$ glyricidia+ PGPR - respectively.

During 90DAT to harvest significantly higher AGR(0.45) and CGR(1.96) was observed in treatment $\mathrm{T}_{5}-100 \% \mathrm{RDF}+\mathrm{FYM}+\mathrm{PGPR}$ and $\mathrm{T}_{4}-100 \% \mathrm{RDF}+$ eupatorium equivalent to FYM respectively.

Increase in growth parameters at different growth stage might be due to combined application of chemical fertilizers, organics and bio fertilizers.

In the present study, it was found that the AGR and CGR increased with increase in the crop duration up to 90 days after transplanting. Crop growth rate is widely used character for estimating production efficiency of crop stand and enables to make comparisons between the aspect of study (Watson, 1952).

Among different treatment data on relative growth rate (RGR) showed non-significant differences. Relative growth rate (RGR) was declined with an advancement of the crop growth could be due to decline in the rate of dry matter production. 
Table.1 Morpho-physiological parameters of paddy (Oryza sativa L.) as influenced by integrated nutrient management

\begin{tabular}{|c|c|c|c|c|c|c|}
\hline \multirow[t]{2}{*}{ Treatments } & \multicolumn{6}{|c|}{90 Days after transplanting } \\
\hline & Plant height $(\mathrm{cm})$ & Number of leaves & No. of tillers & $\begin{array}{l}\text { Leaf area } \\
\left(\mathrm{cm}^{2} \text { hill }^{-1}\right)\end{array}$ & LAI & TDM $\left(\mathrm{g} \mathrm{hill}^{-1}\right)$ \\
\hline$T_{1-} 100 \%$ RDF & 78.52 & 55.12 & 15.41 & 461 & 2.31 & 36.90 \\
\hline $\mathrm{T}_{2}-100 \% \mathrm{RDF}+\mathrm{FYM}$ & 84.83 & 58.63 & 17.35 & 618 & 3.09 & 43.08 \\
\hline $\begin{array}{l}\mathrm{T}_{3^{-}} 100 \% \mathrm{RDF}+\text { glyricidia } \\
\text { equivalent to } \mathrm{FYM}\end{array}$ & 85.58 & 66.47 & 19.14 & 906 & 4.53 & 47.30 \\
\hline $\begin{array}{l}\mathrm{T}_{4}-100 \% \mathrm{RDF}+\text { eupatorium } \\
\text { equivalent to } \mathrm{FYM}\end{array}$ & 89.71 & 67.14 & 20.78 & 913 & 4.57 & 50.73 \\
\hline $\mathrm{T}_{5^{-}} 100 \% \mathrm{RDF}+\mathrm{FYM}+\mathrm{PGPR}$ & 93.65 & 70.68 & 22.19 & 1034 & 5.17 & 57.02 \\
\hline$T_{6}-100 \%$ RDF + glyricidia+ PGPR & 90.17 & 69.81 & 21.36 & 975 & 4.87 & 56.28 \\
\hline $\mathrm{T}_{7}-100 \%$ RDF + eupatorium+ PGPR & 85.15 & 63.53 & 19.26 & 840 & 4.20 & 46.32 \\
\hline$T_{8^{-}} 100 \%$ RDF + PGPR & 83.95 & 58.24 & 17.19 & 593 & 2.97 & 40.95 \\
\hline $\begin{array}{l}\mathrm{T}_{9-}-100 \% \mathrm{RDF}+\text { glyricidia }(50 \%)+ \\
\text { eupatorium }(\mathbf{5 0} \%)+\text { PGPR }\end{array}$ & 96.74 & 71.26 & 23.86 & 1098 & 5.49 & 59.69 \\
\hline $\begin{array}{l}\mathrm{T}_{10^{-}} 100 \% \text { RDF + glyricidia }(50 \%)+ \\
\text { eupatorium }(50 \%)\end{array}$ & 84.63 & 60.18 & 18.59 & 704 & 3.52 & 41.25 \\
\hline S. Em \pm & 3.69 & 4.26 & 1.31 & 76 & $\mathbf{0 . 3 7}$ & 3.69 \\
\hline $\mathrm{CD}(\mathrm{P}=\mathbf{0 . 0 5})$ & 10.95 & 12.66 & 3.88 & 225 & 1.12 & 10.98 \\
\hline
\end{tabular}

Note: RDF @ 75:75:90 kg N: $\mathrm{P}_{2} \mathrm{O}_{5}: \mathrm{K}_{2} \mathrm{O} \mathrm{ha}^{-1}$, FYM @ $10 \mathrm{tha}^{-1}$,Glyricidia @ $7.4 \mathrm{t} \mathrm{ha}^{-1}$, Eupatorium @ $8.10 \mathrm{t} \mathrm{ha}^{-1}$, DAT- Day after transplanting 
Table.2 Growth parameters of paddy (Oryza sativa L.) as influenced by integrated nutrient management

\begin{tabular}{|c|c|c|c|c|c|c|}
\hline \multirow[t]{2}{*}{ Treatments } & \multicolumn{3}{|c|}{60 - 90 DAT } & \multicolumn{3}{|c|}{90 DAT- at harvest } \\
\hline & $\begin{array}{c}\text { AGR (g hill } \\
\left.\text { day }^{-1}\right)\end{array}$ & $\begin{array}{l}\operatorname{RGR}\left(\mathrm{g} \mathrm{g}^{-1}\right. \\
\left.\qquad \operatorname{day}^{-1}\right)\end{array}$ & $\begin{array}{c}\text { CGR }\left(\text { g dm }^{-2}\right. \\
\left.\text { day }^{-1}\right)\end{array}$ & $\begin{array}{c}\text { AGR (g hill } \\
\left.\text { day }^{-1}\right)\end{array}$ & $\begin{array}{l}\operatorname{RGR}\left(\mathrm{g} \mathrm{g}^{-1}\right. \\
\left.\qquad \operatorname{day}^{-1}\right)\end{array}$ & $\begin{array}{c}\operatorname{CGR}\left(\mathrm{g} \mathrm{dm}^{-2}\right. \\
\left.\operatorname{day}^{-1}\right)\end{array}$ \\
\hline $\mathrm{T}_{1^{-}}-100 \% \mathrm{RDF}$ & 0.75 & 0.031 & 3.30 & 0.37 & 0.0097 & 1.62 \\
\hline $\mathrm{T}_{2^{-}}-100 \% \mathrm{RDF}+\mathrm{FYM}$ & 0.84 & 0.029 & 3.71 & 0.25 & 0.0049 & 1.08 \\
\hline $\begin{array}{l}\mathrm{T}_{3^{-}} 100 \% \mathrm{RDF}+\text { glyricidia equivalent } \\
\text { to FYM }\end{array}$ & 0.87 & 0.027 & 3.84 & 0.27 & 0.0053 & 1.09 \\
\hline $\begin{array}{l}T_{4-} 100 \% \text { RDF + eupatorium } \\
\text { equivalent to FYM }\end{array}$ & 0.96 & 0.027 & 4.21 & 0.45 & 0.0075 & 1.96 \\
\hline $\mathrm{T}_{5^{-}} 100 \% \mathrm{RDF}+\mathrm{FYM}+\mathrm{PGPR}$ & 1.08 & 0.028 & 4.74 & 0.44 & 0.0069 & 1.92 \\
\hline $\mathrm{T}_{6}-100 \% \mathrm{RDF}+$ glyricidia+ PGPR & 1.09 & 0.028 & 4.80 & 0.36 & 0.0057 & 1.59 \\
\hline$T_{7}-100 \%$ RDF + eupatorium+ PGPR & 0.90 & 0.029 & 3.95 & 0.28 & 0.0045 & 1.10 \\
\hline$T_{8^{-}} 100 \%$ RDF + PGPR & 0.83 & 0.031 & 3.65 & 0.26 & 0.0061 & 1.14 \\
\hline $\begin{array}{l}\text { T}_{9-} 100 \% \text { RDF + glyricidia }(50 \%)+ \\
\text { eupatorium }(50 \%)+\text { PGPR }\end{array}$ & 1.07 & 0.026 & 4.72 & 0.43 & 0.0067 & 1.89 \\
\hline $\begin{array}{l}\mathrm{T}_{10}-100 \% \text { RDF + glyricidia }(50 \%)+ \\
\text { eupatorium }(50 \%)\end{array}$ & 0.75 & 0.026 & 3.28 & 0.38 & 0.0083 & 1.69 \\
\hline S. Em \pm & 0.10 & 0.001 & 0.43 & 0.041 & 0.005 & 0.21 \\
\hline $\mathrm{CD}(\mathrm{P}=0.05)$ & 0.30 & 0.004 & 1.27 & 0.12 & NS & 0.62 \\
\hline
\end{tabular}

Note: RDF @ 75:75:90 kg N: $\mathrm{P}_{2} \mathrm{O}_{5}: \mathrm{K}_{2} \mathrm{O} \mathrm{ha}^{-1}$, FYM @ $10 \mathrm{t} \mathrm{ha}^{-1}$, Glyricidia @ $7.4 \mathrm{t} \mathrm{ha}^{-1}$,Eupatorium @ $8.10 \mathrm{t} \mathrm{ha}^{-1}$, DAT- Day after transplant 
Table.3 Yield and yield attributes of paddy (Oryza sativa L.) as influenced by integrated nutrient management

\begin{tabular}{|c|c|c|c|c|c|c|c|c|}
\hline Treatments & $\begin{array}{c}\text { No. of } \\
\text { productive } \\
\text { tillers hill'-1 }\end{array}$ & $\begin{array}{c}\text { Panicle } \\
\text { length }(\mathrm{cm})\end{array}$ & $\begin{array}{l}\text { Panicle } \\
\text { weight } \\
\left(\mathrm{g} \mathrm{hill} \text { h }^{-1}\right)\end{array}$ & $\begin{array}{l}\text { Total no. } \\
\text { of grains } \\
\text { panicle }^{-1}\end{array}$ & $\begin{array}{l}1000 \text { grain } \\
\text { weight }(g)\end{array}$ & $\begin{array}{c}\text { Grain } \\
\text { yield } \\
\left(\mathrm{kg} \mathrm{ha}^{-1}\right)\end{array}$ & $\begin{array}{c}\text { Straw } \\
\text { yield } \\
\left(\mathrm{kg} \mathrm{ha}^{-1}\right)\end{array}$ & $\begin{array}{l}\text { Harvest } \\
\text { index }\end{array}$ \\
\hline $\mathrm{T}_{1-} \mathbf{1 0 0} \% \mathrm{RDF}$ & 12.20 & 16.49 & 2.56 & 103 & 23.50 & 4952 & 6293 & 0.441 \\
\hline $\mathrm{T}_{2}-100 \% \mathrm{RDF}+\mathrm{FYM}$ & 13.32 & 17.98 & 3.03 & 102 & 24.76 & 5159 & 6451 & 0.443 \\
\hline $\begin{array}{l}\mathrm{T}_{3-} 100 \% \mathrm{RDF}+\text { glyricidia equivalent } \\
\text { to FYM }\end{array}$ & 14.95 & 19.16 & 3.39 & 103 & 25.29 & 5354 & 6870 & 0.440 \\
\hline $\begin{array}{l}\mathrm{T}_{4-100} \% \mathrm{RDF}+\text { eupatorium } \\
\text { equivalent to FYM }\end{array}$ & 16.02 & 20.37 & 3.58 & 108 & 24.99 & 5527 & 7094 & 0.439 \\
\hline $\mathrm{T}_{5-100} \% \mathrm{RDF}+\mathrm{FYM}+\mathrm{PGPR}$ & 17.72 & 21.22 & 3.95 & 121 & 25.80 & 5652 & 7295 & 0.436 \\
\hline $\mathrm{T}_{6-100} \% \mathrm{RDF}+$ glyricidia+ PGPR & 16.40 & 20.58 & 3.81 & 118 & 25.15 & 5565 & 7144 & 0.439 \\
\hline $\mathrm{T}_{7}-100 \% \mathrm{RDF}+$ eupatorium+ PGPR & 13.68 & 18.82 & 3.22 & 116 & 24.83 & 5289 & 6807 & 0.435 \\
\hline $\mathrm{T}_{8-} \mathbf{1 0 0} \% \mathrm{RDF}+\mathrm{PGPR}$ & 13.18 & 17.65 & 2.98 & 98 & 23.68 & 5130 & 6389 & 0.445 \\
\hline $\begin{array}{l}\text { T }_{9-100} \% \text { RDF + glyricidia }(50 \%)+ \\
\text { eupatorium }(50 \%)+\text { PGPR }\end{array}$ & 18.41 & 22.29 & 4.13 & 128 & 25.36 & 5843 & 7477 & 0.438 \\
\hline $\begin{array}{l}\mathrm{T}_{10-}-100 \% \mathrm{RDF}+\text { glyricidia }(50 \%)+ \\
\text { eupatorium }(50 \%)\end{array}$ & 13.39 & 18.66 & 3.15 & 106 & 24.97 & 5197 & 6573 & 0.442 \\
\hline S. Em \pm & 1.19 & 1.02 & 0.26 & 4.24 & 0.92 & 203 & 284 & 0.013 \\
\hline $\mathrm{CD}(\mathrm{P}=\mathbf{0 . 0 5})$ & 3.55 & 3.03 & 0.78 & 13.00 & NS & 603 & 838 & NS \\
\hline
\end{tabular}

Note: RDF @ 75:75:90 kg N: $\mathrm{P}_{2} \mathrm{O}_{5}: \mathrm{K}_{2} \mathrm{O} \mathrm{ha}^{-1}$, FYM @ $10 \mathrm{t} \mathrm{ha}^{-1}$, Glyricidia @ $7.4 \mathrm{t} \mathrm{ha}^{-1}$,Eupatorium @ 8.10 t ha ${ }^{-1}$, DAT- Day after transplanting 


\section{Yield and yield attributes}

Influence of integrated nutrient management on yield and yield attributes at harvest is presented in Table-3. Among various treatments maximum number of productive tillers per hill(18.41), panicle length $(22.29 \mathrm{~cm})$, panicle weight $\left(4.13 \mathrm{~g}\right.$ hill $\left.^{-1}\right)$, total number of grains $\left(128\right.$ panicle $\left.^{-1}\right), 1000$ grain weight $(25.36 \mathrm{~g})$, grain yield $\left(5843 \mathrm{~kg} \mathrm{ha}^{-1}\right)$ and straw yield $\left(7477 \mathrm{~kg} \mathrm{ha}^{-1}\right)$ was recorded by the application of 100 per cent recommended dose of fertilizers + Glyricidia (50\%) + eupatorium $(50 \%)+\operatorname{PGPR}\left(\mathrm{T}_{9}\right)$, followed by 100 per cent recommended dose of fertilizers $+\mathrm{FYM}+\operatorname{PGPR}\left(\mathrm{T}_{5}\right)$. Higher yield and yield attributing parameters may be due to better carbon assimilation and accumulation of carbohydrates in the plant. However, maximum Harvest index was observed in $\mathrm{T}_{8^{-}}$ $100 \%$ RDF + PGPR followed by $\mathrm{T}_{2}-100 \%$ $\mathrm{RDF}+\mathrm{FYM}$.

Number of productive tillers increased with supplemental addition of $\mathrm{N}$ and $\mathrm{K}$ through green manures, which could be attributed to the influence of $\mathrm{N}$ on leaf development, tiller production and increasing leaf photosynthetic activity (Ntanson and Koutroubas, 2002). In RDF treatment, insufficient nutrients for filling of grains led to diminished grain number per panicle; thus, in this state, lower competition is the cause of decreased hallow grain percentage in panicle. The results were in accordance with the findings of Esfehani $e t$ al., (2005) and (Ramachandra Prasad et al., 2016).

Grain yield and straw yield of paddy was significantly influenced by the combined application of 100 per cent recommended dose of fertilizers, green manures and biofertilizers. Increase in 1000 grain weight, grain yield and straw with treatment $\mathrm{T}_{9}-\mathrm{RDF}+$ glyricidia $(50$ $\%)+$ eupatorium (50 \%) + PGPR followed by $\mathrm{T}_{5}-100$ per cent $\mathrm{RDF}+\mathrm{FYM}+\mathrm{PGPR}$.
This might be due to better nitrogen and chlorophyll content of plant at panicle emergence and grain filling period consequent to an increasing availability of nitrogen to rice crop maintained complimentary source-sink relationship. Thus the increase in growth and yield owing to the application of $\mathrm{N}$-fertilizers may be due to nitrogen is an important constituents of nucleotides, proteins, chlorophyll and many enzymes, involved in various metabolic processes which have direct impact on vegetative and reproductive phases of plants. With increment of nitrogen fertilizer, grain yield increased relatively, but further increase in nitrogen level produced higher straw yield. These findings are supported by Indira (2005), (Thomas and Thomas, 2009). Ashley et al., (2006), (Amit Kaul et al., 2015) and (Glick, 2012).

\section{References}

Amit, K., Kaul, R., Anil, K., Seema, C., and Dass, A., 2015, Importance of green manuring in sustainable agriculture. Popular Kheti, 3(2): 8-12.

Ashley, M. K., Grant, M. and Grabov, A., 2006, Plant response to potassium deficiencies: a role for potassium transport proteins. Journal of Experimental Botany, 57(2): 425-436.

Esfehani, M., Sadrzade, S. M., Kavoosi, M. and Dabagh-Mohammad-Nasab, A., 2005, Study the effect of different levels of nitrogen and potassium fertilizers on growth, grain yield, yield components of rice (Oryza sativa) cv. Khazar. Iran Agron. J., 7(3): 226-241.

Gangwar, S. and Dubey, M., 2013, Impact of integrated nutrient management practices on quality of basmati rice (Oryza sativa L.). Crop Res., 46(3):610.

Glick, B. R., 2012, Plant Growth-Promoting Bacteria-Mechanisms and Applications. Hindawi Publishing 
Corporation, Scientifica, Waterloo, Canada: 13-17.

Indira, C., 2005, Effect of nitrogen fertilizers and organic manurers on growth, yield and quality of hybrid rice (Oryza sativa). J. Central European Agric., 6(4): 611-618.

Jamilah, M. and Juniarti, Y., 2017, Chromolaena odorata compost affected soil chemical and rice crop (Oryza sativa L.). Agrotech., 6(1): 1-6.

Macedo, M. O., Resende, A. S. Garcia. P. C., Boddey. R. M., Jantalia S. Urquiaga., Campello, E. F. C. and Franco, A. A., 2008, Changes in soil $\mathrm{C}$ and $\mathrm{N}$ stock and nutrient dynamics 13 years after recovery of degraded land using leguminous nitrogen-fixing trees: Forest Ecol. Manag., 255: 1516-1524.

Ntanson, D. A. and Koutroubas, S. D., 2002, Dry matter and $\mathrm{N}$ accumulation and translocation for India and Japonica rice under Mediterranean conditions. Field Crop Res., 74: 93-101.

Ogundare, S. K., Babatunde, I. J., Aduloju, M. O. and Hinmikaiye, A.S., 2015, Effect of Chromolaena Odorata residue and urea fertilizer on plant available nitrogen, growth and yield of maize (Zea mays) in Ejiba, Kogi State, Nigeria. Int. J. Res. Agric. Forestry, 2(8): $1-5$.

Prakash, H. C., Shekar, B. G., Jagadeesh, B.
R., Kalayanmurthy, K. N. and Sivalingam, M. L. 2008, Paddy cropping system for sustaining soil health and rice yield in cavery command area. Res. Crops, 9(1):7-9.

Ramachandra Prasad, T. V., Kumar Naik, A. H. and Basavaraja Naik, T., 2016, Influence of Chromolaena odorata compost on growth and yield of finger millet. J. Agric. Vet. Sci., 9(7): 20-24.

Singh, R and Agarwal, S.K. 2001, Analysis of growth and productivity of wheat in relation to levels of FYM and nitrogen. Indian J. Plant Physio., 6:279-283

Sunil Kumar, G. K., Shrivastava., Navaz, M. O., Navrang, S., Pali,G. P. and Pandey, N., 2017, Impact of various organic sources of nitrogen on growth, yield attributes and yield of scented rice under irrigated condition of Chhattisgarh plains. J. Pharma. Phytochem, 6(6):1388-1391.

Thomas, T. C. and Thomas, A. C., 2009, Vital role of potassium in the osmotic mechanism of stomata sperture modulation and its link with potassium deficiency. Plant Signal Behavour, 4(3):240-243.

Watson, D. J., 1952, The physiological basis of variation in yield. Advances in Agronomy, 4:101-145.

\section{How to cite this article:}

Shreeshail, M. Hanumanthappa and Ganapathi, M. 2020. Influence of Integrated Nutrient Management on Paddy (Oryza sativa 1.) under Hill Zone of Karnataka. Int.J.Curr.Microbiol.App.Sci. 9(02): 2508-2515. doi: https://doi.org/10.20546/ijcmas.2020.902.285 